\title{
KECEMASAN MATEMATIKA PADA MAHASISWA PENDIDIKAN GURU SEKOLAH DASAR
}

\author{
Natalia Rosalina Rawa \\ STKIP Citra Bakti Ngada, Nusa Tenggara Timur \\ rawarah@gmail.com \\ Putu Agus Eka Mastika Yasa \\ STKIP Citra Bakti Ngada, Nusa Tenggara Timur \\ eka_masthie@yahoo.co.id
}

\begin{abstract}
Abstrak
Penelitian ini bertujuan untuk mendeskripsikan tingkat kecemasan matematika dan mengidentifikasi faktor-faktor penyebab kecemasan matematika. Subjek penelitian ini adalah mahasiswa pendidikan guru sekolah dasar di STKIP Citra Bakti, Nusa Tenggara Timur yang berjumlah 32 orang. Teknik pengumpulan data pada penelitian ini menggunakan angket, wawancara dan dokumentasi. Dari hasil penelitian diperoleh deskripsi tingkat kecemasan matematika pendidikan guru sekolah dasar diantaranya yaitu sebanyak 29 mahasiswa $(90,63 \%)$ terindikasi mengalami kecemasan dimana 12 mahasiswa $(37 \%)$ mengalami kecemasan berat, 9 mahasiswa $(28,12 \%)$ mengalami kecemasan sedang, dan 8 mahasiswa (25\%) mengalami kecemasan ringan. Sementara hanya terdapat 3 mahasiswa $(9,38 \%)$ yang tidak terindikasi mengalami kecemasan matematika. Faktor-faktor penyebab kecemasan matematika yang dialami mahasiswa pendidikan guru sekolah dasar antara lain disebabkan oleh rendahnya keyakinan dalam belajar matematika (self-efficacy) yang dipengaruhi oleh persepsi mahasiswa tentang matematika, frekuensi belajar matematika yang minim, situasi pembelajaran yang kurang kondusif, riwayat kemampuan matematis yang rendah, materi yang semakin kompleks, dan tuntutan hasil belajar harus memuaskan.
\end{abstract}

Kata Kunci: Kecemasan Matematika, Mahasiswa Pendidikan Guru Sekolah Dasar

\begin{abstract}
This present study aims at describing students' mathematics anxiety level on subject as well as identifying the factors that influence it. The subjects in this study are 32 students from primary teacher education department in STKIP Citra Bakti, East Nusa Tenggara. Further, the data collection method utilises questionnaire, interview, and documentation. This study reveals that 29 students $(90.63 \%)$ are indicated to have anxiety in mathematics learning. This is distributed to 12 students $(37 \%)$ are having great anxiety, 9 students $(28.12 \%)$ are in moderate level, and 8 students have low anxiety. On the other hand, there are only 3 students $(9.38 \%$ ) who are not indicated to have anxiety in mathematics learning. In addition, there are also some factors that influence students' anxiety level such as low self-efficacy, students' perception, low frequency of mathematics learning, less comfortable learning atmosphere, low mathematical ability, the complexity of the materials, and the minimum requirements which are too high
\end{abstract}

Keywords: Math Anxiety, Primary School Teacher Education

\section{Pendahuluan}

Matematika merupakan ilmu universal yang mendasari perkembangan teknologi modern dan mempunyai peran penting dalam berbagai disiplin dan memajukan daya pikir manusia. Confederation of British Industry (2006) menyatakan bahwa ilmu dasar matematika merupakan suatu kebutuhan yang harus dipenuhi dalam kehidupan sehari-hari, terlebih lagi untuk mendapatkan pekerjaan. Anitah W, dkk (2008: 11) menyatakan bahwa matematika merupakan raja dari semua ilmu. Matematika disebut sebagai raja dari semua ilmu karena dalam ilmu pengetahuan lainnya, perkembangan dan penemuannya bergantung pada matematika. Ranjan dan Gunendra Chandra (2013) mengungkapkan bahwa ilmu matematika merupakan sumber dari perkembangan teknologi dan ilmu pengetahuan yang lainnya.

Matematika merupakan ilmu pengetahuan yang sangat penting. Shadiq (2007) menyatakan bahwa matematika dapat dianggap sebagai pemrediksi kecerdasan seseorang. Misalnya, jika ada seseorang yang berhasil mempelajari matematika dengan baik maka orang tersebut diprediksi akan mampu sukses pada bidang-bidang yang lainnya. Begitu pula sebaliknya, jika seseorang mengalami kesulitan dibidang matematika, maka diprediksi bahwa orang tersebut juga akan mengalami kesulitan dalam mempelajari hal-hal lainnya. Namun masyarakat secara umum dan siswa pada khususnya menganggap matematika adalah mata pelajaran yang sulit untuk dipelajari. Cockroft (Krismanto, 2007) menyebutkan bahwa siswa tumbuh tanpa menyukai matematika sama sekali. Mereka menganggap matematika adalah pelajaran yang tidak menyenangkan, sulit dipahami dengan 
berbagai tugas atau soal yang menyulitkan, dan tidak setiap orang dapat mengerjakannya. Dodeen, et al., 2014 dan Smetackova (2015) menyebutkan beberapa faktor yang berperan penting dalam prestasi matematika siswa, yaitu: motivasi, kecemasan, dan sikap terhadap matematika.

Kecemasan merupakan suatu perasaan tidak nyaman yang sering terjadi di dalam kehidupan sehari-hari. Hurlock (1997) berpendapat bahwa kecemasan merupakan sebuah ungkapan perasaan individu terhadap suatu situasi yang dapat diekspresikan melalui beberapa cara, yaitu dengan cara yang mudah dikenali seperti kekhawatiran individu dan individu menjadi mudah marah. Wihastuti, Supriati \& Jahriah (2014) menyatakan bahwa kecemasan adalah gangguan alam perasaan (afektif) yang di tandai dengan perasaan ketakutan atau kekhawatiran yang mendalam dan berkelanjutan, tidak mengalami gangguan dalam menilai realitas, kepribadian masih tetap utuh, prilaku dapat terganggu tetapi masih dalam batas-batas normal. Setiawati (2011) menambahkan bahwa kecemasan peserta didik dapat terjadi kapan saja, misalnya saja peserta didik mengalami kecemasan bila disuruh maju ke depan kelas, kecemasan berbicara di muka umum, dan sebagainya.

Kecemasan matematika berdampak buruk terhadap pelaksanaan dan hasil dari pembelajaran matematika. Menurut hasil penelitian Olaniyan dan Medinat (2015), siswa yang terindikasi kecemasan matematika akan berpendapat bahwa matematika itu sulit untuk dipelajari, siswa tidak menyukai matematika, menolak mengerjakan tugas matematika, bahkan sampai membolos pada saat jam mata pelajaran matematika. Hal ini dikarenakan kecemasan matematika menyebabkan siswa kesulitan untuk belajar dan mengaplikasikan konsep matematika (Gleason, 2008).

Kecemasan siswa dalam menghadapi matematika dikarenakan adanya beberapa faktor, yaitu faktor inteligensi, faktor di dalam diri siswa dan faktor lingkungan. Zeidner (1998) mengatakan bahwa kecemasan siswa terhadap pelajaran matematika dikarenakan kurangnya ketertarikan siswa terhadap pelajaran matematika. Kurangnya ketertarikan siswa terhadap pelajaran matematika disebabkan oleh pengaruh inteligensi siswa dalam pelajaran matematika, siswa yang memiliki inteligensi tinggi akan cenderung lebih tertarik dan akan lebih evaluatif terhadap pelajaran matematika sedangkan siswa yang memiliki inteligensi rendah akan kurang tertarik dan kurang evaluatif terhadap pelajaran matematika. Pendapat lain dikemukakan oleh Wigfield dan Meece (dalam Ormrod, 2004) menjelaskan penyebab kecemasan terhadap pelajaran matematika adalah ketidak percayaan diri dalam menyelesaikan soal-soal matematika dan memiliki emosi negatif terhadap soal-soal matematika. Pendapat berbeda juga disebutkan Hudoyo (Nawangsari, 2009), kecemasan seseorang terhadap matematika dipengaruhi oleh pengalaman belajar matematika yang diterima orang tersebut di masa lampau.

Bukan hanya siswa yang mengalami kecemasan matematika, mahasiswa juga mengalaminya. Khatoon \& Mahmood (2010) mengungkapkan bahwa kecemasan matematika ditemukan pada siswa sejak sekolah dasar, sekolah menengah, hingga jenjang perguruan tinggi. Malinsky, dkk. (2006) menemukan bahwa kecemasan matematika merupakan masalah yang umum pada diri seseorang yang berada pada jenjang perguruan tinggi. Bursal \& Paznokas (2006) melaporkan bahwa secara signifikan, persentase banyak calon guru yang memiliki kecemasan matematika lebih tinggi dibandingkan dengan mahasiswa jenjang S1 lainnya. Lebih lanjut, Boyd, dkk. (2014) menemukan bahwa 40\% dari subjek yang diteliti merasa cemas dalam mengajar matematika.

Sebagaian besar mahasiswa beranggapan bahwa matematika adalah mata kuliah yang sangat sulit dan rumit, sehingga peserta didik malas untuk mempelajarinya akibatnya nilai yang diperoleh peserta didik menjadi tidak maksimal (Tambunan, 2006, Widodo, 2011, Widodo, 2013). Kecemasan tersebut meningkat sejalan dengan semakin tingginya jenjang pendidikan mereka (Jackson \& Leffingwell, 1999; Renga \& Dalla, dalam Herman, 2005). Hal ini terjadi sejalan dengan semakin kompleksnya materi matematika yang siswa pelajari, sehingga mereka membutuhkan motivasi yang lebih besar dan rasa percaya diri yang lebih tinggi untuk dapat menjawab setiap tantangan dalam pembelajaran matematika.

Kecemasan matematika ini dapat berakibat pada tidak aktifnya mahasiswa calon guru untuk mengembangkan kompetensinya serta cenderung menghindari aktivitas matematika. Choppin (2011) menemukan bahwa guru dengan kecemasan matematika relatif mengandalkan pengajaran berbasis buku teks yang fokus pada keterampilan dasar dan minim kegiatan diskusi kelas. Selain itu, guru tersebut juga minim dalam menerapkan berbagai strategi pembelajaran di kelas matematikanya (Swars, dkk., 2007). Peker \& Ertekin (2011) menemukan bahwa calon guru dengan kecemasan matematika memiliki kecenderungan mengajar secara klasikal dan tidak tepat dalam memilih pendekatan pembelajaran yang digunakan. Selain itu, calon guru tersebut meluangkan sedikit waktu untuk mengajarkan konsep kepada siswanya. Sementara itu, Buchmann (Haciomeroglu, 2013) 
mengungkapkan bahwa guru yang menyukai matematika meluangkan waktu untuk matematika hingga $50 \%$ lebih banyak dibandingkan guru yang tidak menyukai pelajaran matematika.

Cooke, dkk. (2011) menyatakan bahwa kecemasan matematika seseorang dapat diidentifikasi dari 4 domain, yaitu mathematics knowledge/understanding, somatic, cognitive, dan attitude. Mathematics knowledge/understanding berkaitan dengan hal-hal seperti munculnya pikiran bahwa dirinya tidak cukup tahu tentang matematika. Somatic berkaitan dengan perubahan pada keadaan tubuh individu misalnya tubuh berkeringat atau jantung berdebar cepat. Cognitive berkaitan dengan perubahan pada kognitif seseorang ketika berhadapan dengan matematika, seperti tidak dapat berpikir jernih atau menjadi lupa hal-hal yang biasanya dapat ia ingat. Attitude berkaitan dengan sikap yang muncul ketika seseorang memiliki kecemasan matematika, misalnya ia tidak percaya diri untuk melakukan hal yang diminta atau enggan untuk melakukannya.

Hartatik dan Fitriyah (2017) menegaskan bahwa guru sekolah dasar merupakan ujung tombak dalam menyukseskan pembelajaran di tingkat sekolah dasar. Merujuk pada tugas guru sekolah dasar sebagai guru kelas, maka mereka diharuskan menguasai semua bidang studi termasuk khususnya matematika. Stoehr (2017) menyebutkan bahwa guru sekolah dasar sebaiknya memiliki kompetensi dan kepercayaan diri yang tinggi dalam mengajarkan matematika. Wilson (2009) menyatakan bahwa memiliki pemahaman dan pengetahuan yang baik tentang matematika, serta percaya diri terhadap kompetensinya merupakan sebuah kebutuhan dasar bagi seorang guru. Oleh karena itu, pentingnya seorang mahasiswa calon guru sekolah dasar menyadari segala sesuatu yang harus dipersiapkan dalam mengajar baik dari segi internal maupun eksternal.

Dalam kegiatan perkuliahan dosen perlu mempertimbangkan berbagai aspek misalnya kondisi psikologis dan gaya belajar mahasiswa pada saat memilih metode atau strategi. Rawa (2017: 242) menyatakan bahwa tingkat metakognisi mahasiswa pendidikan guru sekolah dasar dengan gaya belajar introvert berada pada kategori reflective use, dimana penggunaan pemikirannya baik sebelum dan sesudah atau bahkan selama proses berlangsung mempertimbangkan kelanjutan dan perbaikan hasil pemikirannya, sehingga mahasiswa dengan gaya belajar ini mampu menyelesaikan masalah matematika dengan benar. Sedangkan tingkat metakognisi mahasiswa pendidikan guru sekolah dasar dengan gaya belajar extrovert berada pada kategori strategic use dan aware use, dimana penggunaan pemikirannya baik sebelum dan sesudah atau bahkan selama proses berlangsung kurang mempertimbangkan kelanjutan dan perbaikan hasil pemikirannya, sehingga ada beberapa masalah matematika yang tidak tepat hasil perhitungannya. Sehingga penelitian ini difokuskan pada kondisi psikologis mahasiswa pendidikan guru sekolah dasar yaitu kecemasan terhadap matematika. Mahasiswa pendidikan guru sekolah dasar yang dimaksud dalam penelitian ini adalah mahasiswa pendidikan guru sekolah dasar di STKIP Citra Bakti, Nusa Tenggara Timur. Dari uraian tersebut, tujuan penelitian ini adalah mendeskripsikan tingkat kecemasan matematika dan mengidentifikasi faktor-faktor penyebab kecemasan matematika mahasiswa pendidikan guru sekolah dasar. 


\section{Metode}

Jenis penelitian ini adalah deskriptif kualitatif. Menurut Afifuddin (2009:56), penelitian kualitatif adalah jenis penelitian yang temuannya tidak diperoleh melalui prosedur statistik inferensial atau bentuk hitungan lainnya. Pendekatan deskriptif berarti penelitian ini berusaha menjelaskan atau mendiskripsikan suatu gejala, peristiwa, kejadian, yang terjadi pada saat sekarang. Penelitian ini mendeskripsikan faktor-faktor penyebab kecemasan matematika mahasiswa pendidikan guru sekolah dasar.

Subjek penelitian adalah seluruh mahasiswa pendidikan guru sekolah dasar STKIP Citra Bakti semester II Tahun Akademik 2017/2018. Pemilihan subjek ini didasari dengan pertimbangan bahwa mahasiswa pada tingkat ini sudah atau sedang memprogram mata kuliah Konsep Dasar Matematika (3 sks). Hal ini memungkinkan bagi peneliti untuk mengkaji apakah mahasiswa pendidikan guru sekolah dasar memiliki kecemasan matematika atau tidak. Teknik pengumpulan data dilakukan dengan angket, wawancara dan dokumentasi.

Analisis data hasil angket dilakukan dengan menghitung skor yang diperoleh masing-masing mahasiswa. Kemudian mahasiswa diklasifikasikan atau dikelompokkan berdasarkan skor yang diperolehnya. Data mahasiswa yang tergolong dalam kategori kecemasan berat diambil untuk dilakukan langkah selanjutnya yaitu wawancara. Penilaian kategori kecemasan mengikuti rentang pengklasifikasian skor angket yang dapat dilihat pada tabel 1 berikut.

Tabel 1. Rentangan Skor Angket Kecemasan Matematika

\begin{tabular}{cl}
\hline Rentangan skor & \multicolumn{1}{c}{ Kategori } \\
\hline $10-19$ & tidak ada kecemasan \\
$20-29$ & kecemasan ringan \\
$30-39$ & kecemasan sedang \\
$40-50$ & kecemasan berat \\
\hline
\end{tabular}

Dalam menganalisis data hasil angket, dokumentasi, dan wawancara dilakukan melalui tiga langkah, yakni reduksi data, penyajian data dan penarikan kesimpulan. Berikut uraian dari ketiga langkah penganalisisan data tersebut:

a. Reduksi Data

1) Merangkum hasil dokumentasi dan wawancara yang telah dilakukan sebelumnya.

2) Memilah hasil dokumentasi dan wawancara yang sesuai dengan kebutuhan penelitian.

3) Hasil dokumentasi dan wawancara yang tersisa disederhanakan menjadi susunan bahasa yang baik, kemudian ditransformasikan ke dalam catatan.

b. Penyajian Data

1) Menyajikan dokumentasi dalam bentuk uraian.

2) Menyajikan hasil angket tingkat kecemasan matematika yang telah diisi oleh mahasiswa pendidikan guru sekolah dasar STKIP Citra Bakti dalam bentuk tabel disertai uraian.

3) Menyajikan hasil wawancara faktor-faktor penyebab kecemasan matematika yang telah direkam dalam bentuk uraian.

c. Penarikan Kesimpulan atau Verifikasi

Langkah yang dilakukan setelah penyajian data yakni menarik kesimpulan atau verifikasi. Verifikasi merupakan sebagian dari suatu kegiatan dari konfigurasi yang utuh sehingga mampu menjawab pertanyaan penelitian dan tujuan penelitian.

\section{Hasil Dan Pembahasan}

\section{Hasil Penelitian}

Kegiatan Penelitian ini diawali dengan dengan melakukan studi pendahuluan (pleminary research) mengenai kecemasan matematika berdasarkan kajian teori dan hasil penelitian terdahulu yang relevan. Berdasarkan studi pendahuluan tersebut disusun instrumen penelitian yang terdiri atas angket kecemasan matematika dan pedoman wawancara terkait kecemasan matematika yang kemudian divalidasi. Angket kecemasan matematika disebarkan kepada 32 mahasiswa pendidikan guru sekolah dasar yang telah menempuh mata kuliah Konsep Dasar Matematika (3 sks) di STKIP Citra Bakti.

Selanjutnya dilakukan analisis hasil pengisian angket kecemasan matematika yang dapat dilihat pada tabel 2 berikut ini. 
Tabel 2. Analisis Data Angket Kecemasan Matematika

\begin{tabular}{clcc}
\hline Rentangan skor & \multicolumn{1}{c}{ Kategori } & Frekuensi & Persentase \\
\hline $10-19$ & tidak ada kecemasan & 3 & $9,38 \%$ \\
$20-29$ & kecemasan ringan & 8 & $25,00 \%$ \\
$30-39$ & kecemasan sedang & 9 & $28,12 \%$ \\
$40-50$ & kecemasan berat & 12 & $37,50 \%$ \\
\hline
\end{tabular}

Selanjutnya dilakukan wawancara terhadap 12 mahasiswa yang tergolong dalam kategori kecemasan berat agar dapat merepresentasikan kecemasan matematika mahasiswa pendidikan guru sekolah dasar. Wawancara dilakukan untuk mengetahui faktor-faktor penyebab kecemasan matematika.

Berdasarkan hasil wawancara terhadap 12 mahasiswa terpilih, dirangkum ke dalam 4 hal pokok yang dapat dijadikan data pendukung faktor peyebab kecemasan matematika, yaitu:

1. Persepsi mahasiswa tentang matematika

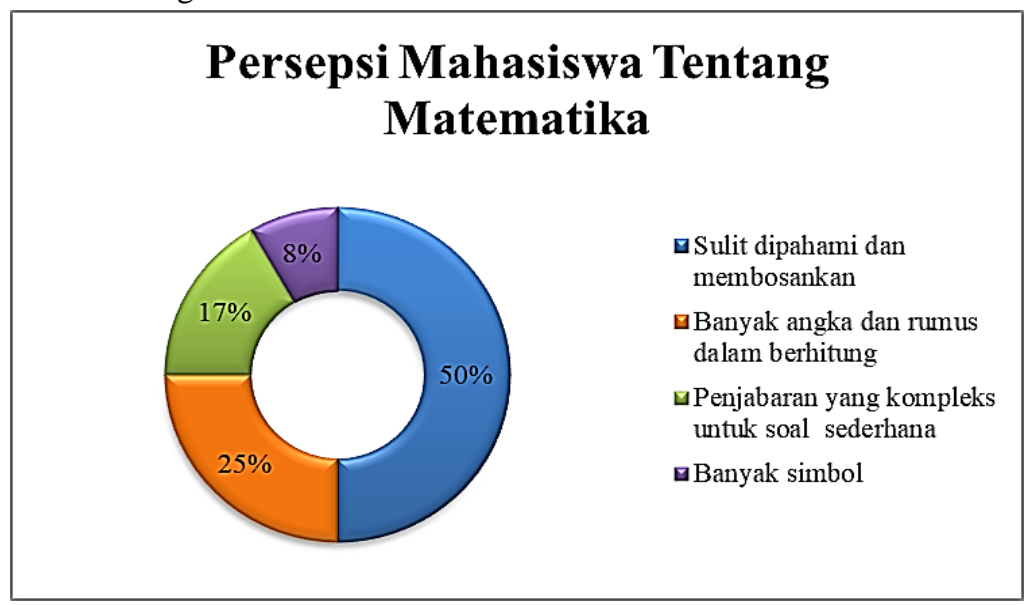

Gambar 1. Persepsi Mahasiswa Tentang Matematika

Hasil wawancara mengenai persepsi mahasiswa terhadap matematika diperoleh sebanyak 6 mahasiswa menyatakan matematika sulit dipahami dan membosankan, 3 mahasiswa menyatakan matematika sangat abstrak karena berupa rumus dan angka saja, 2 mahasiswa menyatakan matematika membutuhkan penjabaran kompleks untuk soal yang sederhana, dan 1 mahasiswa lainnya menyatakan matematika banyak menggunakan simbolsimbol yang membingungkan.

2. Frekuensi belajar matematika di luar perkuliahan

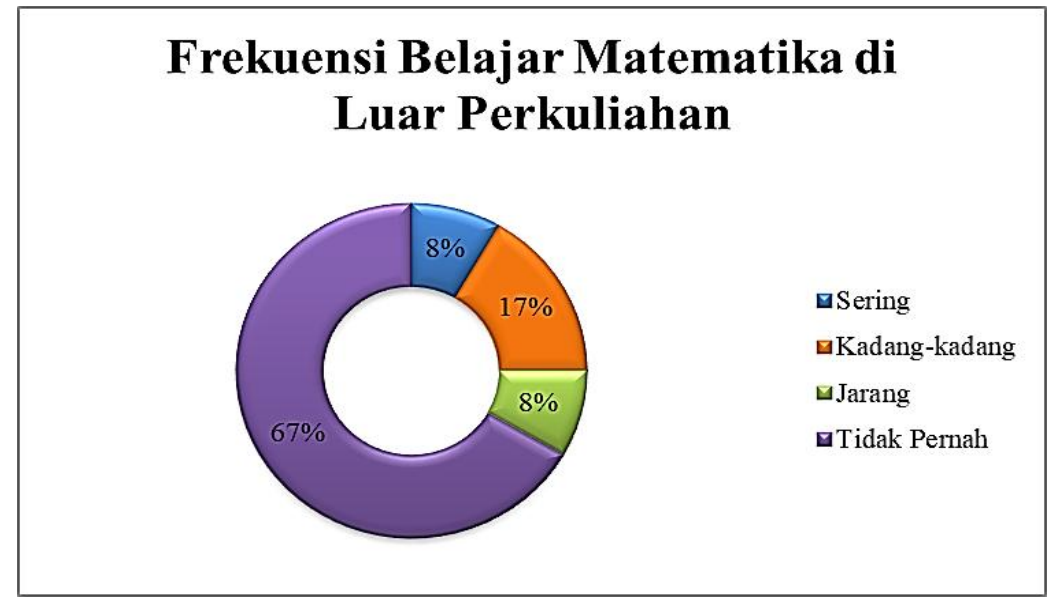

Gambar 2. Frekuensi Belajar Matematika di Luar Perkuliahan

Hasil wawancara mengenai frekuensi belajar matematika di luar perkuliahan, sebanyak 1 mahasiswa menyatakan sering belajar matematika paling banyak dua kali seminggu, sebanyak 2 mahasiswa menyatakan kadang-kadang belajar matematika yaitu hanya pada saat diberikan tugas rumah oleh dosen, sebanyak 1 mahasiswa menyatakan jarang belajar matematika yaitu sehari sebelum perkuliahan, dan sebanyak 8 mahasiswa menyatakan tidak pernah belajar matematika di luar perkuliahan. 
3. Situasi yang memicu terjadinya kecemasan matematika

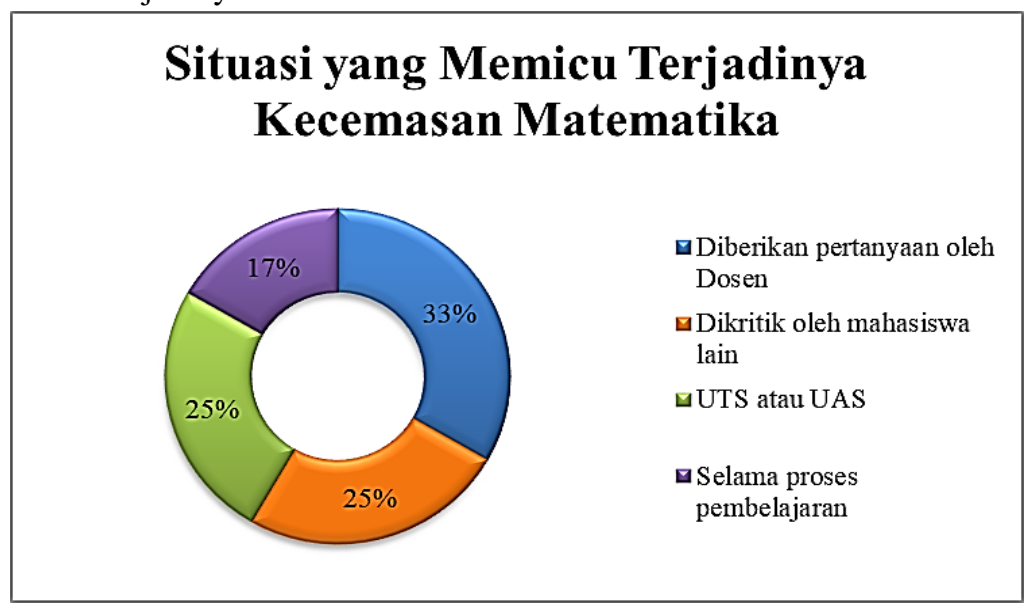

Gambar 3. Situasi yang Memicu Terjadinya Kecemasan Matematika

Hasil wawancara mengenai penyebab kecemasan matematika yang dialami mahasiswa diperoleh sebanyak 4 mahasiswa mengemukakan kecemasan timbul pada saat diberikan pertanyaan oleh dosen, 3 mahasiswa mengemukan kecemasan timbul pada saat dikritik oleh mahasiswa lain, 3 mahasiswa mengemukakan kecemasan timbul pada saat UTS maupun UAS, dan 2 mahasiswa mengemukakan kecemasan timbul selama proses pembelajaran berlangsung.

4. Alasan mahasiswa mengalami kecemasan matematika

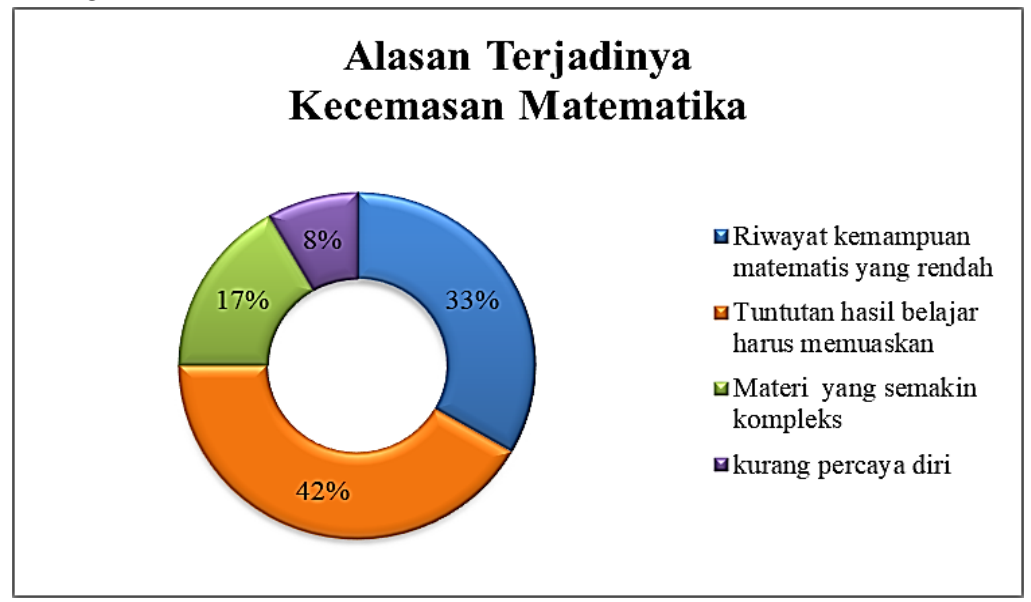

Gambar 4. Alasan Terjadinya Kecemasan Matematika

Hasil wawancara mengenai alasan mahasiswa mengalami kecemasan matematika diperoleh sebanyak 4 mahasiswa mengalami kecemasan matematika dengan alasan riwayat kemampuan matematis yang rendah, 5 mahasiswa dengan alasan tuntutan untuk memperoleh hasil belajar yang memuaskan, 2 mahasiswa dengan alasan materi matematika yang semakin kompleks dan 1 mahasiswa dengan alasan kurang percaya diri. 
5. Pendapat mahasiswa mengenai cara untuk mengatasi kecemasan matematika

\title{
Pendapat Mahasiswa Tentang Cara Mengatasi Kecemasan Matematika
}

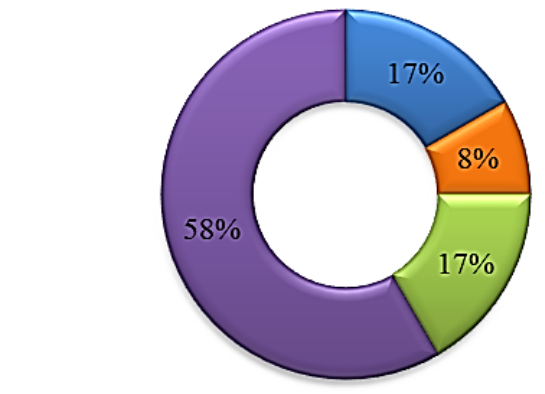

\author{
- Strategi pembelajaran \\ yang bervariasi \\ $\square$ Perbaikan gay a mengajar \\ Dosen/Pengajar \\ $\checkmark$ Koneksi matematika \\ dengan kehidupan nyata \\ 口Meningkatkan self- \\ efficacy
}

Gambar 5. Pendapat Mahasiswa Tentang Cara Kecemasan Matematika

Hasil wawancara mengenai pendapat mahasiswa untuk mengatasi kecemasan matematika diperoleh sebanyak 2 mahasiswa menyarankan strategi pembelajaran yang bervariasi, sebanyak 1 mahasiswa menyarankan perbaikan gaya mengajar dosen/pengajar, sebanyak 2 mahasiswa menyarankan matematika perlu dikaitkan dengan berbagai aspek kehidupan nyata, sebanyak 7 mahasiswa menyarankan agar mahasiswa dapat meningkatkan self-efficacy atau keyakinan dalam belajar matematika.

\section{Pembahasan}

Berdasakan analisis data hasil angket menunjukkan sebanyak 29 mahasiswa (90,63\%) terindikasi mengalami kecemasan dimana 12 mahasiswa (37\%) mengalami kecemasan berat, 9 mahasiswa $(28,12 \%)$ mengalami kecemasan sedang, dan 8 mahasiswa (25\%) mengalami kecemasan ringan. Sementara hanya terdapat 3 mahasiswa $(9,38 \%)$ yang tidak terindikasi mengalami kecemasan matematika. Hasil ini menunjukkan sangat kecil mahasiswa pendidikan guru sekolah dasar yang tidak mengalami kecemasan matematika. Dari hasil wawancara terhadap 12 mahasiswa pendidikan guru sekolah dasar, mengindikasikan beberapa penyebab kecemasan matematika antara lain, (1) Rendahnya keyakinan dalam belajar matematika (self-efficacy), (2) frekuensi belajar matematika yang minim, (3) situasi pembelajaran yang kurang kondusif, (4) riwayat kemampuan matematis yang rendah, (5) materi yang semakin kompleks, (6) tuntutan hasil belajar harus memuaskan.

Kecemasan matematika yang terjadi pada mahasiswa pendidikan guru sekolah dasar STKIP Citra Bakti timbul karena kurangnya keyakinan dalam diri untuk belajar matematika sehingga matematika sulit dipahami dan terkesan membosankan. Hal ini senada dengan hasil penelitian terdahulu yang menyatakan bahwa sebagaian besar mahasiswa beranggapan bahwa matematika adalah mata kuliah yang sangat sulit dan rumit, sehingga peserta didik malas untuk mempelajarinya akibatnya nilai yang diperoleh peserta didik menjadi tidak maksimal (Tambunan, 2006, Widodo, 2011, Widodo, 2013). Selain itu matematika dipandang sebagai pembelajaran yang terdiri atas banyak angka dan juga rumus, hal ini terlihat dari persepsi mahasiswa tentang matematika dalam kutipan wawancara bersama Dionisia berikut ini:

"Matematika ni rumit sekali dibandingkan mata pelajaran yang lain dan saya tidak suka matematika sejak saya masih SD, banyak angka atau simbol dalam matematika tu yang selalu buat saya binggung untuk hitung, apalagi hafal rumus yang banyak-banyak, tidak heran nilai matematika saya selalu tidak bagus."

Persepsi mahasiswa lainnya tentang matematika adalah matematika mengandung banyak simbolsimbol yang sulit untuk dingat dalam jangka waktu yang lama, selain itu soal-soal sederhana dalam matematika membutuhkan jawaban dengan penjabaran yang kompleks. Kecemasan ini terus berlanjut pada fase minimnya frekuensi belajar matematika di luar jam perkuliahan. Hal ini terlihat dari hasil wawancara yang menunjukkan sebanyak $67 \%$ mahasiswa tidak pernah belajar matematika di luar jam perkuliahan matematika, $8 \%$ mahasiswa belajar matematika sehari sebelum perkuliahan, $17 \%$ mahasiswa belajar matematika hanya pada saat diberikan tugas rumah oleh dosen dan $8 \%$ mahasiswa lainnya belajar matematika paling banyak dua kali seminggu. 
Minimnya waktu belajar matematika menyebabkan mahasiswa tidak siap dalam menghadapi situasi pembelajaran di dalam kelas. Situasi pembelajaran juga berpengaruh pada tingkat kecemasan matematika. Setiawati (2011) mengemukakan bahwa kecemasan peserta didik dapat terjadi kapan saja, misalnya saja peserta didik mengalami kecemasan bila disuruh maju ke depan kelas, kecemasan berbicara di muka umum, dan sebagainya. Beberapa situasi yang rentan menimbulkan kecemasan adalah pada saat dosen mengajukan pertanyaan secara lisan atau meminta mahasiswa secara acak untuk menyelesaikan masalah matematika di papan tulis. Bagi mahasiswa yang menguasai materi matematika tentu bukanlah hal yang menakutkan dalam menghadapi pertanyaan dosen, sebaliknya mahasiswa yang tidak menguasai matematika tentu menjadi momok yang menakutkan. Hal ini terlihat dari kutipan wawancara bersama Theodorik berikut ini.

"Saya sering rasa tidak nyaman pada saat dosen mengajukan pertanyaan secara lisan. Kalau diminta mengerjakan di papan tulis, saya butuh waktu yang tidak sedikit untuk menemukan solusinya bahkan sempat tanya teman di sebelah saya. Saya selalu cari aman untuk menghindari pertanyaan dosen, biasanya saya minta ijin untuk keluar kelas dengan alasan pergi ke toilet."

Kecemasan serupa dialami mahasiswa lain sebanyak 33\%, dan 25\% mahasiswa lainnya merasa cemas ketika dikritik oleh teman pada saat menjawab pertanyaan teman dalam diskusi kelompok di kelas, sedangkan 25 $\%$ mahasiswa merasa cemas ketika mengikuti ujian baik UTS maupun UAS. Bahkan ada mahasiswa yang memiliki tingkat kecemasan tertinggi karena merasa cemas selama proses pembelajaran matematika berlangsung yaitu sebanyak $17 \%$.

Kecemasan matematika terjadi karena beberapa alasan, diantaranya adalah tuntutan hasil belajar matematika harus memuaskan. Sebanyak $42 \%$ mahasiswa mengaku sangat cemas jika hasil belajar matematika rendah dalam hal ini pada mata kuliah Konsep Dasar Matematika. Konsep Dasar Matematika merupakan mata kuliah prasyarat untuk dapat memprogram mata kuliah Pembelajaran Matematika SD. Ketentuan Konsep Dasar Matematika sebagai mata kuliah prasyarat ini tentu memberikan kecemasan yang siginifikan bagi mahasiswa, seperti yang terekam dalam wawancara bersama Marlenia berikut ini.

"Saya merasa berat karena matematika diprogram pada beberapa semester, apalagi KDM merupakan mata kuliah prasayarat yang harus lulus dengan nilai minimal B untuk bisa program pembelajaran matematika SD."

Kecemasan matematika juga terjadi dengan alasan riwayat kemampuan matematis yang dimiliki mahasiswa pendidikan guru sekolah dasar tergolong rendah. Hal ini senada dengan penelitian yang dilakukan Rawa, dkk (2016) yang mengkaji tentang salah satu kemampuan matematis yaitu kemampuan koneksi matematis mahasiswa pendidikan guru sekolah dasar STKIP Citra Bakti. Hasil penelitian menunjukkan bahwa kemampuan koneksi matematis mahasiswa pendidikan guru sekolah dasar secara keseluruhan tergolong sangat rendah $(57,3 \%)$. Kemampuan koneksi matematis mahasiswa pada aspek koneksi ide-ide matematis dalam satu topik yang sama tergolong sedang $(72,5 \%)$, pada aspek koneksi ide-ide matematis dalam satu topik dengan topik yang lain tergolong sangat rendah $(57,5 \%)$, dan pada aspek koneksi ide-ide matematis dalam konteks kehidupan sehari-hari tergolong sangat rendah $(41,88 \%)$. Alasan kecemasan matematika lainnya adalah materi matematika pada jenjang perguruan tinggi lebih kompleks dibandingkan matematika di sekolah pada umumnya.

Dari berbagai faktor dan alasan terjadinya kecemasan matematika beberapa mahasiswa memberikan saran untuk mengatasi permasalahan ini, diantaranya adalah perlu adanya variasi strategi pembelajaran, perbaikan gaya mengajar dosen, mengaitkan matematika dengan kehidupan sehari-hari, dan meningkatkan keyakinan diri mahasiswa akan matematika (self-efficacy).

\section{Simpulan}

Berdasarkan hasil penelitian dan pembahasan dapat dismpulkan bahwa sebanyak 29 mahasiswa $(90,63 \%)$ terindikasi mengalami kecemasan dimana 12 mahasiswa (37\%) mengalami kecemasan berat, 9 mahasiswa (28,12\%) mengalami kecemasan sedang, dan 8 mahasiswa (25\%) mengalami kecemasan ringan. Sementara hanya terdapat 3 mahasiswa $(9,38 \%)$ yang tidak terindikasi mengalami kecemasan matematika. Faktor - faktor penyebab kecemasan matematika yang dialami mahasiswa pendidikan guru sekolah dasar antara lain disebabkan oleh rendahnya keyakinan dalam belajar matematika (self-efficacy) yang dipengaruhi oleh persepsi mahasiswa tentang matematika, frekuensi belajar matematika yang minim, situasi pembelajaran yang kurang kondusif, riwayat kemampuan matematis yang rendah, materi yang semakin kompleks, dan tuntutan hasil belajar harus memuaskan. Dari beberapa penyebab kecemasan matematika, maka upaya yang dapat dilakukan untuk meminimalisir kecemasan matematika adalah dosen perlu 
melakukan variasi strategi pembelajaran dan perbaikan gaya mengajar di dalam kelas. Dosen perlu mengaitkan materi matematika dengan kehidupan nyata agar mahasiswa dapat mengubah persepsi mereka tentang matematika yang sulit dan membosankan. Selain itu dosen perlu melakukan scaffolding bagi mahasiswa untuk meningkatkan keyakinan diri mahasiswa akan matematika (self-efficacy). Saran kepada penelitian selanjutnya adalah perlu adanya penelitian yang lebih lanjut mengenai cara mengatasi kecemasan matematika bagi mahasiswa. Selain itu, kecemasan matematika juga penting untuk diteliti tidak hanya pada mahasiswa, melainkan pada siswa jenjang SD, SMP dan SMA.

\section{Daftar Pustaka}

Afifudin. (2009). Metodologi Kualitatif. Bandung: Pustaka Setia

Anitah W., Sri, Janet Trineke Manoy, \& Susanah. (2008). Strategi Pembelajaran Matematika. Jakarta : Universitas Terbuka.

Boyd, W., Foster, A., Smith, J., \& Boyd, W.E. (2014). Feeling Good about Teaching Mathematics: Addressing Anxiety amongst Pre-Service Teacher. Creative Education, 5, 207-207.

Bursal, M. \& Paznokas, L. (2006). Mathematics Anxiety and Pre-service Elementary Teacherse Confidence to Teach Mathematics and Science. School Science and Mathematics, 106 (4), 173-179.

Choppin, J. (2011). The Role of Local Theories: Teacher Knowledge and Its Impact on Engaging Students with Challenging Task. Mathematics Education Education Research Journal, 23 (5), 5-25.

Confederation of British Industry. (2006). Working on the three RS Employers' priorities for functional skill in Mathematics and English. Confederation of British Industry. Diakses pada 16 Februari 2018 (http://eprints.ums.ac.id/42367/1/Naskah\%20Publikasi.pdf).

Cooke, A., Cavanagh, R., Hurst, C., \& Sparrow, L. (2011). Situasional Effects of Mathematics Anxiety in Preservice Teacher Education. Makalah disajikan pada 2011 AARE International Research in Education Conference, Melbourne, Australia.

Dodeen, H. M., Abdelfattah, F., \& Alshumrani, S. (2014). Test-taking Skills of Secondary Students: the Relationship with Motivation, Attitudes, Anxiety and Attitudes Towards Tests. South African Journal of Education, 34(2), 01-18.

Gleason, J. (2008). Relationship between Pre-service Elementary Teachers ${ }^{\text {ee }}$ Mathematics Anxiety and Content Knowledge for Teaching. Journal of Mathematics Science and Mathematics Education, 3 (1), 39- 47.

Haciomeroglu, G. (2013). Mathematics Anxiety and Mathematics Beliefs: What Is the Relationship in Elementary Pre-service Teachers? IUMPST: The Journal, 5.

Hartatik, S. \& Fitriyah, F.K. (2017). Identifikasi Kecemasan Matematika Pada Mahasiswa Program Studi Pendidikan Guru Sekolah Dasar. Jurnal Bimbingan Konseling Indonesia. 2(2). 31 - 33.

Herman, T. (2005). Mengajar dan Belajar Matematika dengan Pemahaman, (Online), (http://file.upi.edu/Direktori/D\%20-\%20FPMIPA/JUR.

\%20PEND.\%20MATEMATIKAA/196210111991011\%20\%20TATANG\%20HERMAN/Artikel/Artikel 13.pdf, diakses 3 Maret 2018).

Hurlock, E.B. (1997). Psikologi Perkembangan: Suatu Pendekatan Sepanjang Rentang Kehidupan. Alih

Khatoon, T. \& Mahmood, S. (2010). Mathematics Anxiety Among Secondary School Students in India and its Relationship to Achievement in Mathematics. European Journal of Social Science, 16 (1), 75-86.

Malinsky, M., dkk.. (2006). Math Anxiety in Pre-Service Elementary School Teacher. Education, 127 (2), 274279.

Nawangsari, N.A.F. (2001). Pengaruh Self-Efficacy dan Expectancy-Value terhadap Kecemasan Menghadapi Pelajaran Matematika. Jurnal Psikologi Pendidikan Insan Media Psikologi, 3(2). 75-88.

Olaniyan, O. M., \& Medinat F. Salman. (2015). "Cause of Mathematics Phobia among Senior High School Students: Empirical Evidence from Nigeria." Journal of the African Educational and Research Network

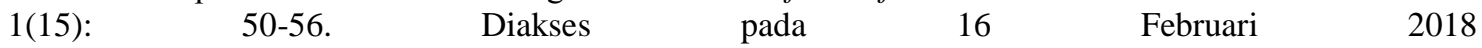
(http://africanresearch.org/africansymposium/archives/TAS15.1/TAS15.1O1 aniyan.pdf).

Ormrod, J.E. (2004). Human Learning (4th Edition). Ohio : Pearson. 
Peker, M. \& Ertekin, E. (2011). The Realationship between Mathematics Teaching Anxiety and Mathematics Anxiety. The Educational Review, 23(1), 213-226.

Ranjan, \& Gunendra Chandra. (2013). "Math Anxiety : The Poor Problem Solving Factor in School Mathematics." International Journal of Scientific and Research Publications 4(3): 1-5. Diakses pada 16 Februari 2018 (http://www.ijsrp.org/research-paper-0413/ijsrp-p16134.pdf).

Rawa, N.R. (2017). Tingkat Metakognisi Mahasiswa Program Studi PGSD Pada Pemecahan Masalah Matematika Ditinjau Dari Gaya Belajar Introvert-Extrovert. Jurnal Tunas Bangsa. 4 (2), 229 - 245.

Rawa, N.R., Sutawidjaja, A. \& Wewe, M. (2016). Kemampuan Koneksi Matematis Mahasiswa PGSD STKIP Citra Bakti Pada Materi Geometri Ruang Sisi Datar. Jurnal Ilmiah Pendidikan Citra Bakti. 3(1), 66 - 78

Setyawati. (2011). Motivasi. Jakarta: Kompas tanggal, 19 Maret 2011.

Shadiq F. (2007). Apa Dan Mengapa Matematika Begitu Penting?. Departemen Pendidikan Nasional Direktorat Jenderal Peningkatan Mutu Pendidik Dan Tenaga Kependidikan Pusat Pengembangan Dan Pemberdayaan Pendidik Dan Tenaga Kependidikan (PPPPTK) Matematika.

Smetackova, I. (2015). Gender Stereotypes, Performance and Identification with Math. ProcediaSocial and Behavioral Sciences, 190, 211-219.

Stoehr, Kathleen Jablon. (2017). Mathematics Anxiety One Size Does Not Fit All. Journal of Teacher Education, Vol 68, Issue 1, 2017.

Swars, S.L., Daane, C.J. \& Giesen, J. (2007). Mathematics Anxiety and Mathematics Teacher Efficacy: What is The Relationship in Elementary Pre-service Teacher. School Science and Mathematics, 106 (7), 306-315.

Tambunan, S. M. (2006). Hubungan Antara Kemampuan Spasial Dengan Prestasi Belajar Matematika. Jurnal Makara, Sosial Humaniora. 10(1): 27 - 32.

Widodo, S. A. (2011). Efektifitas Model Pembelajaran Team Accelerated Instruction Pada Siswa Kelas X SMK Tunas Harapan Tahun Pelajaran 2008- 2009. Prosiding Seminar Nasional Penelitian, Pendidikan dan Penerapan MIPA. 14 Mei 2011, UNY Yogyakarta, Hal. PM1 - PM6.

Widodo, S.A. (2013). Analisis Kesalahan dalam Pemecahan Masalah Divergensi Tipe Membuktikan pada Mahasiswa Matematika. Jurnal Pendidikan Dan Pengajaran. 46 (2): 106 - 113.

Wihastuti, T.A., Supriyati, L.,dan Jahriah, A. (2014). Hubungan Antara Dukungan Keluarga Dengan Tingkat Kecemasan Pada Pasien Pre Operasi Appendictomy Di Ruang Flamboyan RSUD Tarakan Pemerintah Provinsi Kalimantan Timur. Skripsi. Stikes Kusuma Husada.

Wilson, S. (2009). "Better You Than Me": Mathematics Anxiety and Bibliotherapy in Primary Teacher Professional Learning. Dalam Hunter, R., Bicknell, B. \& Burgess, T. (Eds.). Crossing divides: Proceedings of the 32nd annual conference of the Mathematics Education Research Group of Australasia (Volume 2) (hlm. 603-610). Palmerston North, NZ: MERGA.

Zeidner, M. (1998). Test Anxiety: The State of The Art. New York: Kluwer. 